\title{
The Union of Positive and Negative Polarities in the Tale of Love and Madness
}

\author{
Romel M. Aceron ${ }^{1}$ \\ ${ }^{1}$ College of Industrial Technology, Batangas State University, Philippines \\ Correspondence: Dr. Romel M. Aceron, College of Industrial Technology, Batangas State University, Batangas, \\ 4233, Philippines. Tel: 0995-0053-879.
}

Received: December 28, 2018; Accepted: January 17, 2019; Published: January 26, 2019

\begin{abstract}
This paper is an attempt at objectively and critically examining the value of stylistics in literary understanding and interpretation. Literary text is language with its form, purpose, and meaning. In addition, this set of standards in literary text varies according to style. So, stylistics in literature, as another category of linguistics, has been the center of this analysis to solely determine the place of interpretation of literary texts. This literary text analysis is anchored on stylistics and objective criticism to determine, understand and interpret the relevance of the text with regard to its form, purpose, meaning, and style. This attempt is a text-based analysis which examines the literary features of the poem "The Tale of Love and Madness".
\end{abstract}

Keywords: stylistics, text-based analysis, extreme polarities, tale, character, virtue

\section{Introduction}

Before and after the creation of the world, sounds had been heard, produced, and imitated. Sounds, on the other hand, depict one's voice, that is one's life. When people had sensed what they heard, produced, and imitated, they tried to keep all of them. A bit of the past marks its history - cultivated by arts, and eventually by literature. Apparently, literature is said to be the pigment or garment of history as it tells a story before and after the creation. Poetry is genre of literature which is intended to be read, recited, and sung. In the bush of arts, sounds have been written with its representation. Sounds in poetry (text), regardless the poet, appear on its form, purpose, meaning, and style. The poem "The Tale of Love and Madness" is a fiction as it describes the virtues and vices before and after the world was created. As Levi-Strauss emphasized that "what all humans share by virtue of being human are the truths that exist at the level of structure (Klages, 2004).

The text (poem) is allegorical in form. Allegory is a strategy which can be employed in any literary form or genre. According to Abrams (1981), "Allegory is a narrative in which the agents and action, and sometimes the setting as well, are contrived both to make coherent sense on the literal or primary level of signification (significance), and also to signify a second, correlated order of agents, concepts, and events" (p.4). Specifically, "allegory of ideas, i.e. the literal characters represent abstract concepts, and the plot serves to communicate a doctrine or thesis" (p.4). The text in an allegory of ideas seems to be sustained throughout a work, as in The Tale of Love and Madness.

Connecting the positive and the negative seems to be possible in my analysis entitled "The Union of Positive and Negative Polarities in The Tale of Love and Madness". Some literary features found in poem are allegory (form), folktale and oral lore (way of narration), fantasy, and the motif as well. Specifically, symbols/patterns of relationships, allusion, simile through metaphorical construction, and personification are considered in this analysis.

This paper aims to critically analyze (a) the text, (b) the plot and the verbal composition of the text, (c) the characters of the story, and (d) the stylistic features of the text.

\section{Method}

\subsection{Research Design}

This paper used the descriptive-qualitative analysis to describe the distinct features of the text based on the given objectives of the study. Likewise, this study is a text-based analysis that considers understanding, analysis, and interpretation relevant to text. 


\subsection{The Text}

The text subjected to analysis for this attempt is entitled The Tale of Love and Madness.

\subsection{Inter-Coding}

Three experts in the field of language and literature (stylistics) participated as inter-coders or critic of this paper: one PhD professor from the Philippine Normal University, Manila and a part-time professor at the University of Santo Tomas, Manila, who is teaching different English language courses, especially language and literature (stylistics); two PhD in English Language Studies who are handling Language and Literature courses.

\section{Results}

\subsection{Analysis of the text}

The central device in the sustained allegory of ideas is the personification of abstract entities such as virtues and vices. The Tale of Love and Madness allegorizes that before the creation of the world, any of the entities had their virtues and vices that caused chaos and destruction. The passage or extract 1 of this work will indicate the clearcut allegorical process:

\section{Along time ago, before the world was created and humans set foot on it for the first time, virtues and vices floated around and were bored, not knowing what to do.}

\subsection{The Plot and the Verbal Composition of the Text}

Based on the text (poem), the story begins in a narration of what was all about humans before the creation of the world. It is followed by the scenario of being childish or playful which brought chaos and destruction.

\subsection{Characters of the Story}

In the text (poem), the major characters are Love and Madness, while the minor characters are Tenderness, Treason, Fondness, Passion, Lie, and Envy. Theologically, some people (humans) abide in 1 Corinthian 13-love is the most abiding of the virtues. Of the three virtues: Faith, Hope, and Love; the greatest of these is love. Passage or extract 2 presents how Envy tricked Madness.

\section{Madness was getting desperate, unable to find love-Envious of Love, \\ Envy whispered to Madness: "You only need to find Love, and Love is hiding in the rose bush."}

\subsection{Stylistic Features of the Text}

The register of the text sounds to be an entertainment according to purpose. It is allegorical in form which is said to be serious, but it can also be analyzed that the purpose of the poem is amusement. Eventually, the fantasy is also considered as reflected in the feelings of the entities (humans) depicted in the text - that they find one another, maybe for companion, friendship, and love ones. They depict some of the teenagers' perspective as they go along with their playmates and childhood friends. This situation may be considered the root of chaos as the characters (entities) do not know what to do. Their childlike appearance in the text seems to be the reason of being floated and bored. This is also in contrast to the concept of creation in which order is the main cause, but in the story of the text (poem), though they play hide and seek, chaos had been created - leading to destruction.

The text is considered neutral as indicated in the shift of the manner of narration. The shift of narration is found in the following:

A long time ago, ... (Old English Period)

versus

One day, ...

By this time, ...

... from that they on, ... (Late-middle to Modern English Period)

\section{Discussion}

\subsection{Analysis of the Text}

In this analysis, stylistics has been utilized which concentrates on the form, purpose, meaning, and style of the literary text and its other relevant features. This attempt focused on the text alone, which have been the nucleus of this analysis for understanding and interpretation. Abrams (1981) stated that "objective criticism approaches the work as something which stands free from poet, audience, and the environing world. It describes the literary product—a self-sufficient object, or else as a world-in-itself" (p.37). 
Intrinsically, analyzed and judge the complexity, coherence, equilibrium, integrity, and interrelations of its component elements.

Virtues and vices are examples of motif in literature. According to Guerin et al. (2005), "Motif, a type of incident, device, or formula, is a guide to related symbols and patterns of relationships, probing the complex interweaving of ideas within the story" (p.118). Consider the following characters of entities (humans) in the poem according to their motifs:

$$
\begin{aligned}
& \text { love -- } \text { madness/envy (hatred) } \\
& \text { tenderness -- } \quad \text { treason } \\
& \text { fondness -- } \quad \text { lie and/or } \\
& \text { passion -- laziness }
\end{aligned}
$$

As can be noticed to the related symbols and patterns of relationships (motifs), they are interwoven of ideas (complex) within the story as reflected in the way or manner of narration (folktale). Levi-Strauss stressed 'binary pairs' in his discussion about the "structural study of myth and other structural ideas, specifically the opposites, i.e., forming the basic structure of all human cultures, all human ways of thought, and all human satisfying systems". This concept clarifies the human nature and their conditions. It clearly justifies that individual beings have their own ways of thinking, beliefs, or choice of values. Such that binary pair can be a term opposite to other as love to madness/envy (hatred), and other pairs above as extracted from the text or structure (Klages, 2004).

\subsection{The Plot and the Verbal Composition of the Text}

There is only one event, i.e. playing hide and seek, being highlighted in the story of the characters or entities as abstract ideas where life has been personified by abstract characters as Love and Madness (major characters), Tenderness, Treason, Fondness, Lie, Passion, Laziness, and Envy (minor characters).

The event (hide and seek) is also related to some cultural and historical event, like in the Philippine setting, where children play taguan - hiding into different places and corners, i.e. seeker needs to find his target kalaro. Interestingly, in the event, players find their friendship and companions against all odds, because there is love, i.e. the most abiding of all virtues.

\subsection{Characters of the Story}

Explicitly or indirectly, it can be analyzed that the event or situation of madness, who is desperate, angry, and mad at all times was tricked or even puzzled with what Envy whispered to him, like the snake in the Garden of Eve. In the event, Madness made his decision in passage or extract 3 below:

Madness grabbed a wooden pitch fork and stabbed wildly at the rose bush. Madness stabbed and stabbed until a heartbreaking cry made him stop.

\section{Love appeared from the rose bush, covering his face with his hands \\ Between his fingers ran two trickles of blood from his eyes.}

In passages 2 and 3, allusion is defined as "explicit or indirect reference to a person, place, or event, or to another literary work or passage" (Abrams, 1981). A dialogue can be analyzed in the text as reflected in the play hide and seek, i.e. taguan in the Philippine civilization. Most of the players, except Love, were found by Madness - the seeker. In their play, they appeared to be ingenious as manifested in their childlike act. Historically and culturally, children most likely play hide and seek where they find one another according to their virtues and vices. Then, Aceron (2015) emphasized that the level of interaction by individual members or players depends on their level of attitudes and behavior as reflected to their beliefs, emotional reactions, and behavioral tendencies. This could also be meant that individual people process and transform, i.e., passing experiences by means of verbal, imaginal, and other symbols into cognitive models of reality that serve as guides for judgment and action.

\subsection{Stylistic features of the text}

It can be observed that in the form and style, there is a combination of the old English period and the late-middle to modern English period which seems to be neutral in a manner of narration.

There are figures of speech found in the text (poem). Personification (of abstract entities) was found in the text such as virtues and vices. Abstract entities live in abstract ideas depicting the characters of the story in the poem. They are the major and minor characters of the story in the poem who give life and reality as reflected in their play hide and seek. When Madness leaned on against a tree, there is something that made him foreshadow and construct 
what life may be. "A tree symbolizes life (of humans) before and after the creation. It also stands for inexhaustible life, and is therefore equivalent to a symbol of immortality" (Crisp, 1990). However, when Love jumped and hid into a rose bush that made him discover himself as alluring and admirable, though hard to be pleased by others because of his thorns. A metaphorical construction has been considered in the example: Rose is like Love (simile).

The story in a poem is composed of thirteen (13) stanzas. This text has its unique style and form - a narrative text, showing the essential use of words. It can also be considered as free verse as it has no meter and rhythm. The text has its chronological presentation of actions in the event (plot) in the poem. The story in the poem starts with the background - describing the old times before the world was created, where humans exist with virtues and vices. From simple play hide and seek as depicted in the story, instead of order upon creation, chaos was made; perhaps because of their unconscious mind and childlike act. This can be supported by the Two (2) Extreme Polarities known as Yang-yin, a "Chinese symbol, representing the union of the opposite forces of the yang (masculine principle, light, activity, the conscious mind) and the $y$ in (female principle, darkness, passitivity, the unconscious).

Allusion has been found in the story. Bible, myths, or other historical event like the snake in The Garden of Eve is reflected to the event, when Envy whispered to Madness about Love who is hiding in a rose bush. In this metafictional technique, snake symbolizes energy and pure force, evil, corruption, sensuality, destruction, mystery, wisdom - the unconscious. The idea of Envy perhaps corrupted the unconscious mind of Madness that resulted to destruction.

\section{Conclusions}

This paper attempted to analyze the literary features of the text, specifically in a narrative text as poetry. This poem calls the attention of the readers, especially the unconscious mind. Madness stabbed or stuck Love in a rose bush by a wooden pitch fork. Madness's strong desire to find or seek Love resulted to destruction. Love is blind because of Madness's unconscious mind - uncertain and impulsive.

Love is blind. Since Love is the greatest of all virtues, that chaos and destruction - stabbing Love in the rose bush made him blind. Madness would never repair Love's eyes. By Madness's guilt and conscience, he asked Love how he could repair his eyes. Morally speaking, Madness has become Love's guide. This is something that Madness can do for Love, instead of bringing Love's eyes back, or repairing Love's eyes.

Finally, the positive and negative polarities are united in the virtue of love. In the Filipino sense of values, in a stylistics analysis published by Panelo (2015), "Forgiveness is being highlighted as one of the moral ethical values-morally and ethically proper for the Filipino people - where Miguel Syjuco as an author of the novel analyzed, narrated that the character of the story wants the society - who are full of hatred, anger, and bitterness to realize the importance of forgiveness, for Miguel knows that only by unloading all the burdens form one's heart will be set free. Panelo added that Miguel believes that his passion for social transformation could be best achieved when all his bad things in life will be abandoned and be surrendered".

With that, Madness and Love live happily ever after.

This paper calls for further analysis of the text that would concentrate on the psychological attitudes and behavior of individuals, students, adolescent, teenagers whose experiences are revelant in the moral transformation. Thus, an attempt about gender and equality, and stereotyping can also be made in the future stylistics analysis and interpretation.

\section{Acknowledgments}

This stylistics research attempted was partially supported by several people and colleagues from Batangas State University. The ideas or opinions expressed in this paper do not reflect to the organization's policy and the university where this article was made.

\section{References}

Abrams, M. H. (1981). "A glossary of literary terms" (4 ${ }^{\text {th }}$ ed.).

Aceron, R. M. (2015). Freshman students' attitudes and behavior towards adavanced grammar and composition teaching. Asia Pacific Journal of Multidisciplinary Research, 3(4), 85-92.

Crisp, T. (1990). An a to z guide to understanding your unconscious mind: dream dictionary. Dell Publishing. Guerin, et al. (2005). "A handbook of critical approaches to literature" ( $5^{\text {th }}$ ed.). Oxford University Press.

Klages, M. (2004). Claude Levi-Strauss: The structural study of myth and other structuralist ideas. The University of Colorado at Boulder. Compiled by Shawn Urban 2009. 
Panelo, I. C. B. (2015). Passion for Philippine social transformation in the novel ilustrado of Miguel Syjuco. Asia Pacific Journal of Multidisciplinary Research, 4(5), 14-21.

\section{Copyrights}

Copyright for this article is retained by the author(s), with first publication rights granted to the journal.

This is an open-access article distributed under the terms and conditions of the Creative Commons Attribution license (http://creativecommons.org/licenses/by/4.0/). 